\title{
Genç Yetişkinlerde Akılcı Olmayan İnanç İle Öz- Anlayış Arasındaki İlişkide Affetmenin Aracı Rolü
}

DOI: $10.26466 /$ opus.735586

\author{
Defne K1lıç* - Erhan Tunç **
}

* Psikolojik Danışman, Zeytinburnu Rehberlik ve Araştırma Merkezi, İstanbul/Türkiye

E-Posta: defnee.klc@gmail.com

ORCID: 0000-0001-9175-1835

** Dr.Öğretim Üyesi, Gaziantep Üniversitesi, Eğitim Fakültesi, Gaziantep/Türkiye

E-Posta: erhantunc.gaun@gmail.com

ORCID: $\underline{0000-0002-6328-8545}$

\section{Öz}

$B u$ araştırmada genç yetişkinlerin akılcı olmayan inanç ile öz-anlayış düzeyleri arasındaki ilişkide affetme ve affetmenin alt boyutları olan kendini affetme, başkaların affetme ve durumu affetmenin aracı rolleri incelenmiştir. Araştırmanın örneklemini Gaziantep Üniversitesinde çeşitli fakültelerde lisans, yüksek lisans düzeyinde ve formasyon programında öğrenim gören 523 öğrenci oluşturmaktadır. Veri toplama aracı olarak "Akılcı Olmayan İnanç-K Formu", "Öz-Anlayış Ölçeğì" ve "Heartland Affetme Ölçeği" ve araştırmacı tarafindan oluşturulan "Kişisel Bilgi Formu" kullanılmıştır. Verilerin analizinde SPSS makro programı olan PROCESS v.3.3. kullanılmış ve regresyon modelinden yararlanılarak işlem yapılmıştır. Analizler sonucunda akılcı olmayan inanç ile öz-anlayış, affetme, kendini affetme ve durumu affetme arasında negatif yönde, düşük ve anlaml düzeyde ilişki bulunurken, akılcı olmayan inanç ile başkaların affetme arasında anlamlı bir ilişkinin bulunmadığ görülmüştür. Öz-anlayışın; affetme, kendini affetme ve durumu affetme ile pozitif yönde, orta ve anlamlı düzeyde; başkaların affetme ile pozitif yönde, düşük ve anlamlı düzeyde ilişkili olduğu görülmüştür. Akılcı olmayan inanç ile öz-anlayış arasındaki ilişkide aracılık etkisine bakıldığında ise bu ilişkide affetme ve durumu affetmenin kısmi aracl, kendini affetmenin de tam aracı etkisinin olduğu görülmüş̧ür. Akılcı olmayan inanç ile öz-anlayış arasında başkalarım affetmenin aracıllk etkisinin olmadı̆̆ı görülmüştür.

Anahtar kelimeler: akılcı olmayan inanç, öz-anlayış, affetme 


\title{
The Mediator Role of Forgiveness In The Relationship Between Irrational Beliefs And Self-Compassion Among Young Adults
}

\begin{abstract}
In this research, it was examined the mediation role of forgiveness in relationship and the selfforgiveness, forgiveness to others, situation forgiveness which are the sub-dimensions of forgiveness in the relationship between irrational belief and self-understanding in young adults. The participants of the research were 523 students in total (graduate students,master students, students in pedagogic formation program) who study in various departments of Gaziantep University. The research data were collected via Irrational Belief Scale-S Form (IBS-S), Self Compassion Scale, Heartland Forgiveness Scale and Personal Information Form (created by researcher). For statistical analysis PROCESS v.3.3. which is Macro program of SPSS were implemented and regression model were used. The research results indicated that there was a negative correlation and low and significant relationships in the relationships between irrational beliefs and self-compassion, forgiveness, self forgiveness, state forgiveness and there was not a significant relationship between irrational beliefs and others forgiveness. There was a positive correlation, medium and significant relationship between selfcompassion, forgiveness, self forgiveness, state forgiveness and aldo in others forgiveness there was a positive correlation, low and significant relationships. When we look at the mediating effect in the relationship between irrational belief and self-understanding, it is seen that forgiveness and sitiuation forgiveness have a partial mediator effect and self-forgiveness has a full mediating effect in this relationship. There was not a mediator role of forgiveness to others at the relationship between irrational beliefs and self-compassion.
\end{abstract}

Key Words: $\quad$ irrational beliefs, self-compassion, forgiveness 


\section{Giriş}

Genç yetişkinlik dönemini 22-40 yaşları arasında değerlendiren Levinson (1986) bu dönemin kendine has pek çok özelliği bünyesinde barındırdığını ifade eder. Bu dönem bireyde aile kurma, yaratıcı olma, cinsellik, meslek edinme ve hedefleri doğrultusunda ilerleme konularında memnuniyet oluştururken, tüm bu yaşantıların aynı anda olması, bireyin seçimler yapmak durumunda kalması, toplumun ve kendisinin taleplerini karşılamaya çalışması çelişkilere ve strese neden olabilmektedir. Taleplerinin karşılanmasını bekleyen birey amacına ulaşamadığında ise hayal kırıklığına uğramaktadır (Aktu, 2016). Ellis (1973)'e göre bireyler hem akılcı hem de akılcı olmayan şekilde, çarpık düşünme potansiyeli ile dünyaya gelirler. Alanyazında akılcı inançlar sağlıklı, gerçekçi ve işlevsel beklenti ve tercihlerle; akılcı olmayan inançlar ise katı, değişmez, kişiyi sonuca ulaştırmada zorluklara neden olan ve mutlak olması gereken zorunluluklar ve taleplerle tanımlanmıştır (Ellis ve MacLoren, 1998; Akt. Bacanl, 2012). Ellis (1995) akılcı inançların kişinin kendini gerçekleştirme konusunda yardımcı olan etkili düşünceler olduğunu söyler.Bu bağlamda genç yetişkinlik döneminde bireylerin fiziksel ve psikolojik yönden olgunlaştığ1 varsayılır ve karşı karşıya kaldıkları sorunları duygusallıktan uzaklaşıp daha akılcı düşünerek ve davranarak çözmeleri beklenir (K1lı̧, 2013).

Alanyazında insanların beklentileri karşılanmadığında ya da değerlerine ve hedeflerine uygun sonuçlara ulaşamadıklarında kendilerini bekleyen çeşitli duygularla (hayal kırıklığına uğrama, üzülme ve engellenme gibi uygun duygular ya da depresif hissetme, panik olma, kendine güvenememe ve kendine acıma gibi kendine zarar verici uygu olmayan duygular) karşı karşıya kaldıkları belirtilmektedir (McGinn, 1997). Kişiye zarar veren uygun olmayan bu duygular insanların hedeflerine ulaşmalarını engelleyerek kişi için yıpratıcı bir hal alır. Bu duygular pek çok sorunu da beraberinde getirir; insanın çevresiyle ilişkisini bozarak kişinin işlevselliğini bozar (Ellis, 1994). Koffler (2005)'e göre de uygun olmayan duygular herhangi bir işlevi olmadığından bireyi amaçlarından uzaklaştırmakta ve onlara ulaşmasinı engellemektedir (Akt. Kaya, 2010).

İnsanlar kendilerini baskı altında hissettiklerinde ve zorlayıcı yaşam olaylarıyla karşılaştıklarında bu rahatsız edici duygularını değiştiremeyecekleri ve duygularının üzerinde denetimlerinin olmadığına yönelik gerçek- 
çi olmayan düşüncelere kapılırlar. Bu yaşantıların sonucunda bireyde şaşkınlık, utanma, suçluluk gibi acı verici duyguların oluşması insanın yaşantılarını çok fazla ciddiye almasından ve düşüncelere çok fazla odaklanmasından kaynaklanır (Ellis ve Harper, 2017). Bireylerin özellikle genç yetişkinlik döneminde deneyimlerine farklı anlamlar yüklemesi, çözüm arayışlarında başarısız olması ve bunun sonucunda geleceğe dönük umutsuz olması muhtemel görünmektedir (Şahin, 2009). Birey, insanın kontrolünde olan ya da olmayan, kendisini rahatsız eden kaçınılmaz tüm bu yaşantıları "zarif bir şekilde kabul etmeli" ve duygularını iyileştirmek, düzenlemek için çaba sarf etmelidir (Ellis ve Harper, 2017). Garnefski vd. (2001)'ne göre duyguları düzenlemeye çalışmak bireyin bilişsel düzeyde problemlerin üstesinden gelmeye yardımcı olacaktır. Alanyazında öz-anlayış da bir duygusal düzenleme stratejisi olarak kabul gördügüunden (Neff, 2003a) ve kişinin yetersizlik ve başarısızlık gibi yıkıcı duygularıyla başa çıkma becerisi olarak değerlendirildiğinden gerçekçi ve akılcı olmayan inançların azalmasıyla öz-anlayışın da artması beklenen bir durum olacaktır.

Pozitif psikolojide önemli bir kavram olan öz-anlayış; Neff (2003a ve 2003b)'e göre bireyin yaşadığı yıkıcı yaşam olayları sonrasında kendine karşı sert ve acımasız yaklaşması yerine daha kibar ve anlayışla yaklaşması; bu olumsuz olayların birçok insanın deneyimlediği bir yaşantı olduğunu ve kendini yaşamdan soyutlamak yerine kendine acı veren bu duygu ve düşüncelerle bilinçli bir şekilde başa çıkabilmesidir. Öz-anlayış kişinin benliğine yönelik sağlıklı bir tutumdur ve kişinin kendini rahatlatarak acıyla başa çıkmaya yarayan bir yaklaşımdır (Neff, 2003a). Leary vd. (2007)'nin gerçekleştirdikleri çalışma da tüm bu bilgilere açıklayıcı bir özet sunmaktadır. Kendi kendilerine şefkat duyan bireyler günlük yaşamlarında karşılaştıkları pek çok olumsuzluğun içinde kaybolmaktansa problemlerin içerisindeki rollerini kabul etmektedirler. Alanyazın incelendiğinde öz-anlayış; benlik saygisı, daha az anksiyete ve depresyon (Neff, Kirkpatrick, Rude, 2006), daha fazla yaşam memnuniyeti ve pozitif akıl sağlığı (Neff, 2003b), psikolojik sağlık ve daha az özeleştiri (Kirkpatrick, 2005), daha fazla affedici olma (Sarıçam ve Biçer, 2015; Asıcı, 2013) ve yaşamda anlam (Deniz ve vd., 2017) ile ilişkilendirilmiştir. Öz-anlayış ile ilgili yapılan bu çalışmalarla paralel olarak alanyazını destekler nitelikte Neff (2003a) de öz-anlayışı psikolojik iyi oluşa alternatif bir yaklaşım olarak sunmuştur. 
Öz-anlayışın affetme değişkeni ile arasında ilişki olduğu araştırmalarla desteklenmektedir. Mistler (2010) yaptığı araştırmada affetme alt ölçekleri ile öz-anlayış alt ölçekleri arasında güçlü bir pozitif ilişki belirlemiştir. Özanlayış gibi pozitif psikolojide olumlu bir psikolojik özellik olarak kabul gören (Gangdev, 2009) affetme de Lee (2011)'nin yaptığı araştırmada bireyin genel iyi olma hali ile olumlu; kaygı ve depresyon ile olumsuz yönde ilişkilendirilmiştir. Affetmenin pozitif psikolojideki yerini önemseyen Seligman ve vd. (2005) pozitif psikolojideki olumlu müdahalelerin acıları azaltan geleneksel müdahalelere tamamlayıcı nitelikte olabileceğini söylemiştir. Benzer şekilde Wade ve Worthington (2005) da affetmeyi bireyleri iyileştirici bir tedavi yöntemi olarak değerlendirmektedirler.

Affetmenin pek çok tanımı yapılmıştır (North, 1987; Worthinton, 1998; Fitzgibbons, 1986). Enright (1996)'a göre affetmenin gerçekleşebilmesi için haksız yere incinen bireylerin inciten bireye karşı kırgınlıklarını yenebilmeleri ve onlara karşı merhamet duyabilmeleri gerekir. Enright' 'n affetme modeli inciten kişilere karşı duyguları, düşünceleri ve davranışları değiştirmeye odaklıdır. Bu değişimler düşünceler ve duygulardaki değişimi de beraberinde getirerek olumsuzlukları azaltır. Modelin amacı incinmiş bireyin olumlu duygularını, düşüncelerini ve davranışlarını artırmaktır. Böylelikle affeden kişi rahatlama ve huzur sağlayacaktır (Hebl ve Enright, 1993). Affetme modelinin bu yapısı bireyin bilişsel olarak değişimini ve yaşama dair inançlarını akıl süzgecinden geçirmesi gerekliliğini destekler niteliktedir. Yapılan araştırmalarda affetme pek çok olumlu özellik ile ilişkilendirilmiştir: evlilik uyumu (Taysi, 2007), öz-duyarlılık (Asıcı, 2013), psikolojik sağlamlık (Çapan ve Arıcıoğlu, 2014), bilişsel esneklik ve yaşam doyumu (Thompson ve vd., 2005), ahlaki değer ve öz-anlayış (Sarıçam ve Biçer, 2015), psikolojik sağlık (McCullough ve vd., 1998).

Thompson ve vd. (2005) affetmeyi üç alt boyutta ele almışlardır: Kendini affetme, başkalarını affetme ve durumu affetme. Enright (1996)'a göre a) kendini affetme kişinin hatasını kabul etmesi ve kendine duyduğu olumlu duyguların desteklenmesidir. b) başkalarım affetmede de kendini affetme gibi bireyi inciten kişiye karşı yıkıcı duygulardan arınmak ve ona daha olumlu duygularla yönelmek gerekmektedir. Kişi kendini affettiğinde suçlu kişi ile özdeşim kurmaya izin vermektedir ve bu özdeşim başkalarını affetmeyi de kolaylaştırmaktadır (Snow, 1993; Akt. Hall ve Fincham, 2005). c) durumu affetmede ise Thompson ve vd. (2005) kişilerin yaşamla ilgili olumlu beklenti- 
lerini sekteye uğratan olumsuz yaşam olaylarının olumsuz tepkilere yol açabileceğini söyler. Kişi olumsuz yaşantıya verdiği cevabı değiştirdiğinde, beklenmedik bu durumlarda daha olumsuz olan duygularını olumluya ya da nötre dönüştürdüğünde affetme gerçekleşmektedir. Affetme ile ilgili alayazın incelendiğinde affetmenin ruhsal sıkıntılardan kurtulmanın bir yolu olduğu Hebl ve Enright (1993); bireyin hissettiği suçluluktaki azalmanın kendini affetmeyi arttırdığ1 (Hall ve Fincham, 2008) ve bireyde genel iyilik halini artırdığına dair (Lee, 2011) çalışmalar mevcuttur. Tüm bu araştırmalar göz önüne alındığında bireye hata yapma şansı tanımayan, kendine anlayışla yaklaşmasına engel olan, bireyin kendini, başkalarını ya da durumu affetmesini zorlaştırabilen katı, mantıksız, akıldışı inançları ve beklentileri bireylerin ruhsal sıkıntılar yaşamasına neden olabilmektedir.

Bireylerin öz-anlayışlarını artırmada yaşantılar karşısında kişinin kendine neler söylediği, düşünce ve davranışlarını nasıl değerlendirdiği önemlidir. Akılcı olmayan inançlara sahip olan ve bu inançları yaşam amacı olarak gören birey gerçekleşmesi neredeyse imkânsız olan bu inançlar sonucunda başarısız olacak ve hayal kırıklığı hissedecektir. Birey kendine zarar veren bu değerlendirmeleri fark ettiğinde mantık dışı düşünce ve inançları ile yüzleşebilecek, bunları iyileştirebilecek ve psikolojik iyilik halini artıracaktır. Bireyin duygusal sağlığını da etkileyen öz-anlayış kişide işlevsel olmayan düşüncelerin temizlenmesiyle artacaktır (Akın, 2009). Tüm bu olumsuz duyguları terk etme affetme ile olumlu yönde ilişkili görülmektedir ve bireyin kendisine zarar vermeden kendilerini rahatlatabilmeleri ve bu duygulardan sıyrılabilmeleri ile gerçekleşebilecektir. Dahası tüm bu yıkıcı duygulardan sıyrılma kişinin kendine anlayışla yaklaşması yani öz-anlayış ile mümkün olabilecektir (Oral, 2016). Bireylerin yalnızca kendilerine karş1 değil diğer insanlara ve yaşanan olaylara karşı acımasız duyguları ve tutumları da affedici davranarak olumlu yönde değişim gösterecektir. Bu bağlamda bireylerin rahatsız edici duygularının değişiminde ve bu duygularla başa çıkabilmede affetmenin de önemli bir etkisinin olduğu düşünülmektedir.

Son yıllarda özellikle pozitif psikolojinin alanını genişletmesiyle birlikte araştırmaya değer iki kavram öz-anlayış ve affetme birçok araştırmaya konu olmuştur. Öz-anlayışın ve affetmenin olumsuz yaşam olaylarında bireyin yaşamına sağlıklı biçimde devam edebilmesini sağladığı ve iyi oluş hallerini arttırdığı bilinmektedir. Akılcı olmayan inançların da belirlenip uygun 
olmayan düşüncelerin yerine daha gerçekçi düşüncelerin konulmasının bireylerin hem sosyal yaşamlarında hem kişisel yaşamlarında hem de dünyaya ilişkin algılamalarında daha sağlıklı tutum geliştirmelerine ve beklentilerini gerçekçi oluşturmalarına yardımcı olacağı düşünülmektedir. Tüm bu bilgiler ışığında akılcı olmayan inanç ve affetmenin öz-anlayış üzerindeki etkisine bakmak ve bu etkiden hareketle öz-anlayış becerilerinde akılcı olmayan inanç ve affetmenin rolünü belirlemek amaçlanmıştır. Bu amaç çerçevesinde aşağıdaki hipotezler test edilmiştir.

- H1: Affetmenin akılcı olmayan inançlar ile öz-anlayış arasındaki ilişkide aracilık etkisi vardır.

- H2: Kendini affetmenin akılcı olmayan inançlar ile öz-anlayış arasındaki ilişkide aracılık etkisi vardır.

- H3: Başkalarını affetmenin akılcı olmayan inançlar ile öz-anlayış arasındaki ilişkide aracılık etkisi vardır.

- H4: Durumu affetmenin akılcı olmayan inançlar ile öz-anlayış arasındaki ilişkide aracılık etkisi vardır.

\section{Yöntem}

Genç yetişkinlerin akılcı olmayan inançları ile öz-anlayış düzeyleri arasındaki ilişkide affetme, kendini affetme, başkalarını affetme ve durumu affetmenin aracı etkisinin incelendiği bu araştırmada ilişkisel tarama modeli kullanılmıştır. İki veya daha fazla değişken arasındaki ilişkinin ve belirlenen değişimin derecesini açıklayan ilişkisel tarama modeli (Karasar, 2016) bu araştırma için uygun modeli oluşturmaktadır.

\section{Çalışma Grubu}

Araştırmanın çalışma grubunu Gaziantep Üniversitesi'nde 2017-2018 eğitim öğretim yılında lisans, yüksek lisans ve formasyon düzeyinde öğrenim gören 523 öğrenci oluşturmaktadır.

\section{Veri Toplama Araçlarn}

Araştırmada Akılcı Olmayan İnançlar Ölçeği, Öz-Anlayış Ölçeği, Heartland Affetme Ölçeği ve araştırmacı tarafından oluşturulan Kişisel Bilgi Formu kullanılmıştır. Türküm (2003) tarafından geliştirilen Akılcı Olmayan İnançlar Ölçeği Kısa Formu (AOİÖ-K) 5li likert tipi derecelendirme- 
ye sahiptir. Ölçeğin iç tutarlılık katsayısı .81dir ve bu araştırma için hesaplanan Cronbach alfa iç tutarlılık katsayısı .73'tür. Türkçe geçerlik ve güvenirlik çalışması Deniz, Kesici ve Sümer (2008) tarafından yapılan Öz-Anlayış Ölçeği (ÖZAN)'nin iç tutarlılık katsayısı .89dur ve bu araştırma için hesaplanan Cronbach alfa iç tutarlılık katsayısı .89'dur. Türkçeye uyarlama çalışması Bugay ve Demir (2010) tarafından yapılan Heartland Affetme Ölçeği ölçeğinin tamamının Cronbach alfa değeri .81dir ve bu araştırma için hesaplanan Cronbach alfa iç tutarlılık katsayısı .80 'dir. Bir diğer veri toplama aracı da araştırmacı tarafından hazırlanan Kişisel Bilgi Formu'dur.

\section{Veri Toplama Süreci}

Araştırma için gerekli araştırma izinleri alınmış olup sınıflara girilerek araştırmaya katılımın tamamen gönüllüğe dayandığı öğrencilere belirtilmiş ve gönüllü öğrencilerle çalışma gerçekleştirilmiştir. Ölçeklerin doldurulması yaklaşık 15 dakika kadar zaman almıştır.

\section{Verilerin Analizi}

Verilerin analizinde ilk olarak dağılımın normalliğini belirlemek amacıyla veriler üzerine Kolmogorov-Smirnov testi yapılmış ve Normal Q-Q grafiği sonucuna göre verilerin normal dağılım gösterdiği tespit edilmiştir. Ayrıca ölçeklerin güvenirliğini test etmek amacıyla Cronbach Alfa güvenirliği yöntemi kullanılmış, ölçeklere ait güvenirlik katsayılarının; Akılcı Olmayan İnanç Ölçeği için .73, Öz-Anlayış Ölçeği için .89 ve Affetme Ölçeği için .80 olarak bulunmuştur. Affetme alt boyutu olan kendini affetme için Cronbach alfa iç tutarlılık katsayısı .58; başkalarını affetme Cronbach alfa iç tutarlılık katsayısı .71 ve durumu affetme Cronbach alfa iç tutarlılık katsayısı $.67^{\prime}$ dir. Araştırma değişkenleri arasındaki ilişkiyi test etmek amacıyla Pearson Momentler Çarpımı Korelasyon Katsayısı analizi yapılmıştır. Analizlerin devaminda

SPSS makro programı olarak Andrew Hayes tarafından geliştirilen PROCESS v.3.3. eklentisi kullanılarak regresyon modeli oluşturulmuş ve aracılık hipotezleri test edilmiştir. Çok karmaşık modelleri test edebilen PROCESS Makro testinde analizler yalnızca " $\mathrm{p}$ " anlamlılık değeri üzerinden açılanmaz ve normal dağılım koşulu gerektirmeyen bootstrap yöntemi 
kullanılarak güven aralığı hesaplanır. Hesaplanan bu güven aralığı (BootLLCI ve BootULCI) sıfır içermediğinde analiz sonucundaki dolaylı etki istatistiksel olarak anlamlı kabul edilir.

Tüm bu bilgiler ışığında bu araştırmada Hayes (2013)'in belirttiği Model 4 kurulmuştur ve kurulan modelde akılcı olmayan inanç bağımsız değişken, öz-anlayış bağımlı değişken; affetme, kendini affetme, başkalarını affetme ve durumu affetme aracı değişken olarak sunulmuştur. Analizlerde dolaylı etkilerin anlamlılıkları ise \%95 güven aralığında bootstraping yöntemi ile 5000 yeniden örnekleme kullanılarak değerlendirilmiştir. Kurulan modellerde değişkenler arasındaki etkiler $\mathrm{a}$, $\mathrm{b}$ ve $\mathrm{c}$ yolu olarak ve bağımsız değişken $(\mathrm{X})$, bağımlı değişken ( $\mathrm{Y})$ ve aracı değişken (M) olarak kodlanmıştır. Affetme toplam puanı ve alt boyutlar olan kendini affetme, başkalarını affetme ve durumu affetmenin ayrı ayrı aracılık etkileri test edilmiştir.

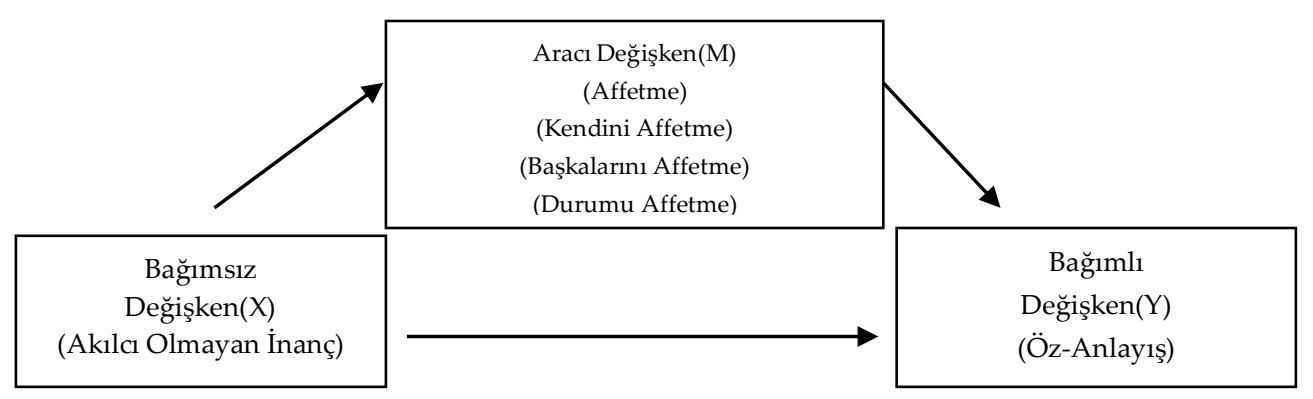

Şekil 1. Aracllk İlişkisini Gösteren Araştırma Modeli

\section{Bulgular}

Araştırmaya Katılan Genç Yetişkinlerin Öz-Anlayış, Affetme ve Akılcı Olmayan İnanç Değişkenleri Arasındaki Korelasyon Analizi Sonuçlarn

Tablo 1. Değişkenlerin birbiriyle olan korelasyonlarına ilişkin pearson momentler çarpımı korelasyon katsayısı sonuçları

\begin{tabular}{lllllll}
\hline & $\mathbf{1}$ & $\mathbf{2}$ & 3 & 4 & $\mathbf{5}$ & $\mathbf{6}$ \\
\hline 1.Öz-Anlayış & 1 & & & & & \\
\hline 2.Affetme &, $65^{* *}$ & 1 & & & & \\
3.KendiniAffetme &, $67^{* *}$ &, $73^{* *}$ & 1 & & & \\
4.BaşkalarınıAffetme &, $27^{* *}$ &, $76^{* *}$ &, $23^{* *}$ & 1 & & \\
5.DurumuAffetme &, $63^{* *}$ &, $86^{* *}$ &, $59^{* *}$ &, $45^{* *}$ & 1 & \\
\hline 6.Akılc1 Olmayan İnanç &,$- 20^{* *}$ &,$- 16^{* *}$ &,$- 22^{* *}$ &,- 00 &,$- 18^{* *}$ & 1 \\
\hline$* * \mathrm{P}<0.01$ & & & & & &
\end{tabular}


Tablo 1.'deki analiz sonuçları incelendiğinde öz-anlayışın, affetme ölçeğinden elde edilen toplam puan $(r=, 650 ; p<0.01)$, kendini affetme $(r=, 670$; $\mathrm{p}<0.01)$, başkalarını affetme $(\mathrm{r}=, 278 ; \mathrm{p}<0.01)$ ve durumu affetme $(\mathrm{r}=, 639$; $\mathrm{p}<0.01)$ arasında pozitif yönde anlamlı düzeyde ilişki olduğu; akılcı olmayan inancın da öz-anlayış $(\mathrm{r}=-, 205 ; \mathrm{p}<0.01)$, affetme toplam puanı $(\mathrm{r}=-, 164$; $\mathrm{p}<0.01)$, kendini affetme $(\mathrm{r}=-, 221 ; \mathrm{p}<0.01)$ ve durumu affetme $(\mathrm{r}=-, 187$; $\mathrm{p}<0.01)$ ile negatif yönde anlamlı düzeyde ilişkili olduğu görülmüştür. Ancak akılcı olmayan inanç ile başkalarını affetme puanları ( $\mathrm{r}=-, 008 ; \mathrm{p}>0.05)$ arasında anlamı ilişki bulunmamıştır.

Akılcı Olmayan İnanç İle Öz-Anlayış Arasındaki İlişkide Affetmenin Aracı Etkisinin İncelendiği Regresyon Analizi Sonuçlarn

Tablo 2. Akılcı olmayan inanç ile öz-anlayış arasındaki ilişkide affetmenin aracı rolüne ilişkin aracılık analizi sonuçları

Affetme (M) Öz-Anlayış (Y)

\begin{tabular}{|c|c|c|c|c|c|c|c|c|}
\hline \multirow[b]{2}{*}{ Yordayıcı Değişkenler } & & & & & & \\
\hline & & $\beta$ & $\mathrm{Se}$ & $\mathrm{p}$ & & $\beta$ & Se & $\mathrm{p}$ \\
\hline Akılcı Olmayan İnanç $(X)$ & $\mathrm{a}$ & -.32 & .08 & $<.001$ & $\mathrm{c}^{\prime}$ & -.19 & .06 & $<.001$ \\
\hline Affetme (M) & & - & - & - & $\mathrm{b}$ & .63 & .03 & $<.001$ \\
\hline Sabit & $i_{1}$ & 100.32 & 4.70 & $<.001$ & $i_{2}$ & 37.88 & 4.89 & $<.001$ \\
\hline & & $\begin{array}{l}\mathrm{R}^{2}=, 027 \\
\mathrm{~F}(1,521\end{array}$ & $46, p$ & & & 5215 & $98, \mathrm{p}$ & \\
\hline
\end{tabular}

Tablo 2.'de görülen değerlere bakıldığında affetmenin akılcı olmayan inanç ile öz-anlayış arasındaki ilişkide aracılık etkisinin olup olmadığını belirlemek amacıyla yapılan regresyon analizi sonucunda " $a$ " yoluna ilişkin regresyon modelinin anlamlı olduğu görülmektedir $\left(R^{2}=.02 ; F(1,521)=14.46\right.$; $\mathrm{p}<.001)$.

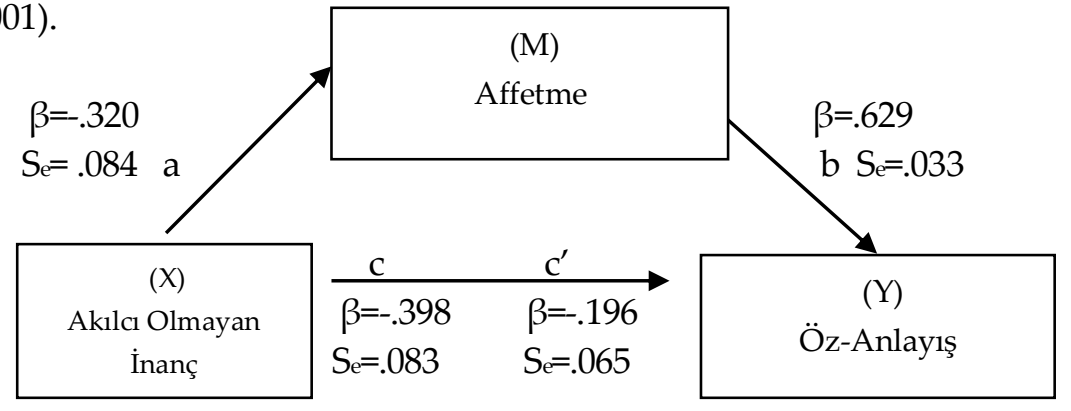

Şekil 2. Affetme Aracıllk İlişkisinin Araştırma Modeli Sonucu 
Şekil 2.'de gösterilen analiz sonuçları incelendiğinde akılcı olmayan inancın affetmeyi anlamlı düzeyde yordadığı $(a=\beta=-.32)$ belirlenmiştir. Akılcı olmayan inancın etkisi kontrol edilirken affetmenin öz-anlayışı anlamlı düzeyde etkilediği görülmektedir $(b=\beta=.63)$. Analizlerin devamında aracı değişken olan affetme modele dahil edildiğinde akılcı olmayan inancın öz-anlayışa başlangıçta var olan etki düzeyinin değiştiği yani affetmenin akılcı olmayan inancın öz-anlayış üzerindeki etkisini -.40'dan -.19'a (c') düşürdüğ̈̈̈ görülmüştür. Bu sonuç affetmenin akılcı olmayan inanç ile özanlayış arasındaki ilişkide kısmi aracı rolünün olduğunu gösterir. Aracı değişkenin anlamlılığına bootsrapping analizi ile bakılmış ve akılcı olmayan inançların affetme aracılığıyla öz-anlayış düzeyi üzerindeki dolaylı etkiler toplamının anlamlı olduğu görülmüştür ( $\beta=-.20, \mathrm{LLCI}=.30$ ile ULCI=-.10). Araştırmaya dair bir diğer bulgu ise akılcı olmayan inançların affetme ile birlikte öz-anlayış düzeylerinde gözlenen varyansın \%43'ünü açıkladı̆̆ıdır $\left(\mathrm{R}^{2}=.43 ; \mathrm{F}(1,521)=197.98 ; \mathrm{p}<.001\right)$. Sonuç olarak H1 hipotezi kabul edilmiştir ve kurulan model doğrulanmıştır.

\section{Akılcı Olmayan İnanç İle Öz-Anlayış Arasındaki İlişkide Kendini Affetmenin Aracı Etkisinin İncelendiği Regresyon Analizi Sonuçları}

Tablo 3. Akılcı olmayan inanç ile öz-anlayış arasındaki ilişkide kendini affetmenin aracı rolüne ilişkin aracılık analizi sonuçlan

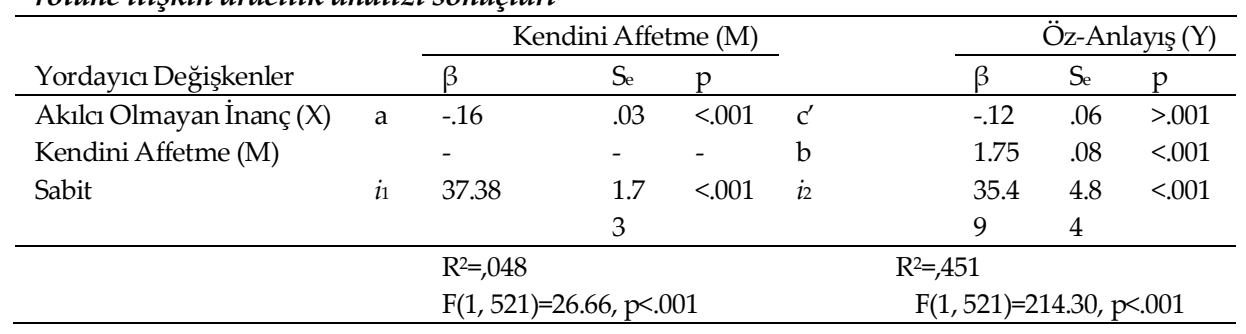

Tablo 3.'te görülen değerlere bakıldığında kendini affetmenin akılcı olmayan inanç ile öz-anlayış arasındaki ilişkide aracıllk etkisinin olup olmadığını belirlemek amacıyla yapılan regresyon analizi sonucunda "a" yoluna ilişkin regresyon modelinin anlamlı olduğu görülmektedir $\left(\mathrm{R}^{2}=.04 ; \mathrm{F}(1\right.$, $521)=26.66, \mathrm{p}<.001)$. 


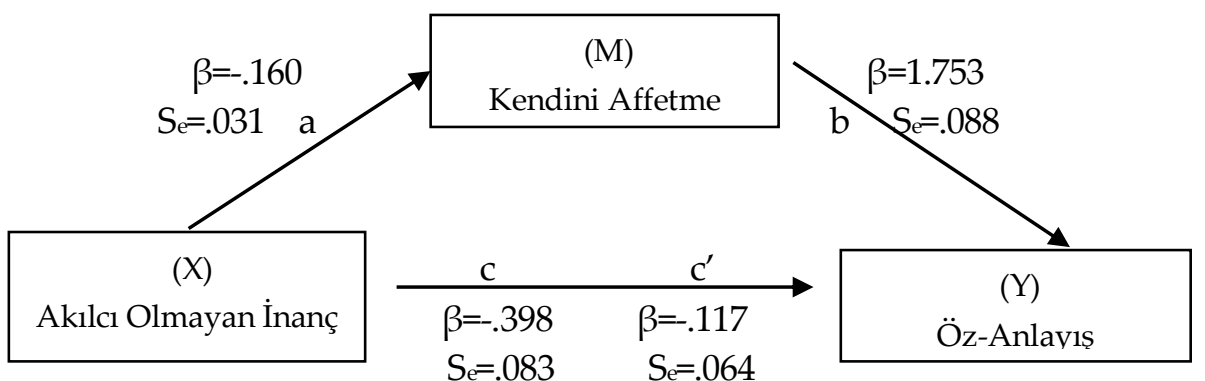

Şekil 3. Kendini Affetme Aracılık İlişkisinin Araştırma Modeli Sonucu

Şekil 3.'te görüldügü üzere akılcı olmayan inanç kendini affetmeyi anlamlı düzeyde etkilemektedir $(a=\beta=-.16 ; p<.001)$. Akılcı olmayan inancm etkisi kontrol edilirken kendini affetmenin öz-anlayışı anlamlı düzeyde etkilediği görülmektedir $(\mathrm{b}=\beta=1.75 ; \mathrm{p}<.001)$. Aracı değişken olan kendini affetme modele dahil edildiğinde akılcı olmayan inancın öz-anlayışa başlangıçta var olan etkisinin değiştiği yani akılcı olmayan inancın öz-anlayış üzerindeki etkisini -.40'dan -.12'ye (c') düşürdügü görülmüştür. Aracllık analizine dair bulgular incelendiğinde kendini affetme aracı değişken olarak modele girdirildiğinde akılcı olmayan inancın öz-anlayış üzerindeki anlamlı etkisi anlamsızlaşmıştır. Sonuç, anlamlılığın kaybolmasıyla kendini affetmenin akılcı olmayan inanç ile öz-anlayış arasındaki ilişkide tam aracı rol oynadığını gösterir. Araştırmada test edilmeye çalışılan aracı modeldeki doğrudan ve dolaylı etkileri belirlemek amaciyla yapılan bootsrapping analizi bulguları, akılcı olmayan inançların kendini affetme aracılığıyla özanlayış düzeyi üzerindeki dolaylı etkiler toplamının anlamlı olduğunu göstermektedir $(\beta=.28$, LLCI=-.39 ile ULCI=-.17). Akılcı olmayan inançların kendini affetme ile birlikte öz-anlayış düzeylerinde gözlenen varyansın $\% 45$ 'ini açıkladığı da söylenebilir $\left(\mathrm{R}^{2}=.45 ; \mathrm{F}(1,521)=214.30, \mathrm{p}<.001\right)$. Sonuç olarak $\mathrm{H} 2$ hipotezi kabul edilmiştir ve kurulan model doğrulanmıştır. 
Akılcı Olmayan İnanç İle Öz-Anlayış Arasındaki İlişkide Başkalarını Affetmenin Aracı Etkisinin İncelendiği Regresyon Analizi Sonuçlarn

Tablo 4. Akılcı olmayan inanç ile öz-anlayış arasındaki ilişkide başkaların affetmenin aracı rolüne ilişkin aracılık analizi sonuçları

\begin{tabular}{|c|c|c|c|c|c|c|c|c|}
\hline \multirow[b]{2}{*}{ Yordayııı Değişkenler } & & \multicolumn{3}{|c|}{ Başkalarını Affetme (M) } & & \multicolumn{3}{|c|}{ Öz-Anlayış (Y) } \\
\hline & & $\beta$ & $\mathrm{Se}$ & $\mathrm{p}$ & & $\beta$ & $\mathrm{Se}_{\mathrm{e}}$ & $\mathrm{p}$ \\
\hline Akılcı Olmayan İnanç (X) & $\mathrm{a}$ & -.00 & .04 & $>.001$ & $c^{\prime}$ & -.39 & .07 & $<.001$ \\
\hline Başkalarını Affetme (M) & & - & - & - & $\mathrm{b}$ & .57 & .08 & $<.001$ \\
\hline Sabit & $i_{1}$ & 26.54 & 2.30 & $<.001$ & $i_{2}$ & 85.94 & 4.99 & $<.001$ \\
\hline & & \multicolumn{3}{|c|}{$\mathrm{R}^{2}=, 000$} & & \multicolumn{3}{|c|}{$\begin{array}{l}\mathrm{R}^{2}=, 118 \\
\mathrm{~F}(1,521)=34,89, \mathrm{p}<.001\end{array}$} \\
\hline
\end{tabular}

Tablo 4.'te görülen değerlere bakıldığında başkalarını affetmenin akılcı olmayan inanç ile öz-anlayış arasındaki ilişkide aracılık etkisinin olup olmadığını belirlemek amaciyla yapılan regresyon analizi sonucunda "a" yoluna ilişkin regresyon modelinin anlamlı olmadığı görülmüştür $\left(\mathrm{R}^{2}=.00\right.$; $\mathrm{F}(1,521)=.03, \mathrm{p}>.001)$.

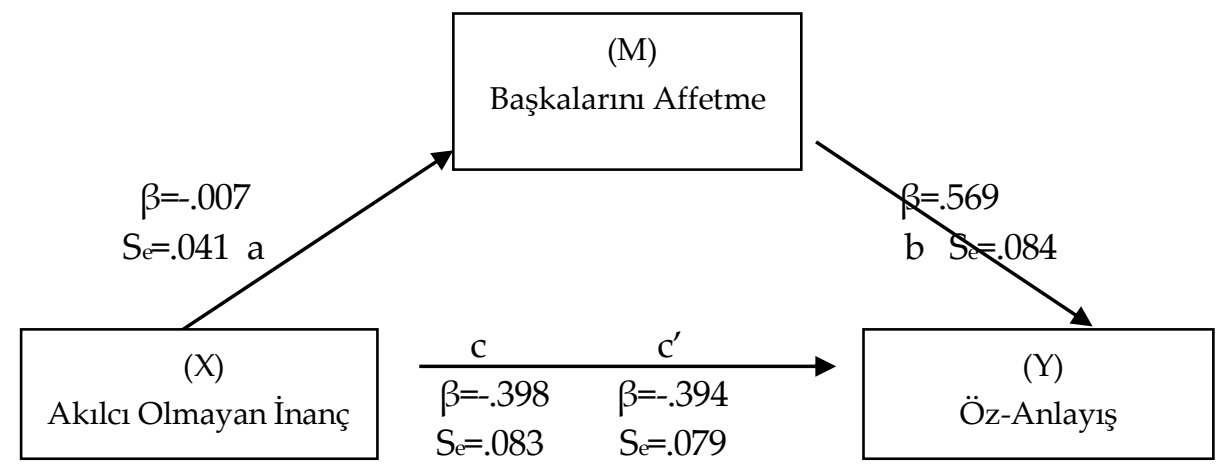

Şekil 4. Başkalarım Affetme Aracılık İlişkisinin Araştırma Modeli Sonucu

Şekil 4.'te de görüldüğü üzere akılcı olmayan inancın başkalarını affetmeyi olumsuz yönde açıkladığı fakat bu açıklamanın anlamlı olmadığı görülmüştür $(\mathrm{a}=\beta=-.00 ; \mathrm{p}>.001)$. Akılcı olmayan inancın etkisi kontrol edilirken başkalarını affetmenin öz-anlayışı olumlu yönde etkilediği görülmüştür $(\mathrm{b}=\beta=.57 ; \mathrm{p}<.001)$. Araştırmada "başkalarını affetmenin akılcı olmayan inançlar ile öz-anlayış arasındaki ilişkide aracılık etkisi vardır" hipotezi test edildiğinde kurulan modelde başkalarını affetmenin akılcı olmayan inanç ile öz-anlayış arasında aracılık etkisinin olmadığı görülmüştür. Bu araştırma 
bulgusu sonucunda bootstapping analizi bulgularının da anlamlı olmadığ görülmüştür ( $\beta=-.00$; BootLLCI= -.04 BootULCI=.03). Sonuç olarak H3 hipotezi reddedilmiştir ve kurulan model doğrulanmamıştır.

Akılcı Olmayan İnanç İle Öz-Anlayış Arasındaki İlişkide Durumu Affetmenin Aracı Etkisinin İncelendiği Regresyon Analizi Sonuçları

Tablo 5.Akılcı olmayan inanç ile öz-anlayış arasındaki ilişkide durumu affetmenin aracı rolüne ilişkin aracılik analizi sonuçlan

\begin{tabular}{|c|c|c|c|c|c|c|c|c|}
\hline \multirow[b]{2}{*}{ Yordayıcı Değişkenler } & & \multicolumn{3}{|c|}{ Durumu Affetme (M) } & & \multicolumn{3}{|c|}{ Öz-Anlayış (Y) } \\
\hline & & $\beta$ & $\mathrm{Se}$ & $\mathrm{p}$ & & $\beta$ & $\mathrm{Se}_{\mathrm{e}}$ & $\mathrm{p}$ \\
\hline Akılcı Olmayan İnanç (X) & $\mathrm{a}$ & -.15 & .03 & $<.001$ & $c^{\prime}$ & -.17 & .06 & $<.001$ \\
\hline Durumu Affetme (M) & & - & - & - & $\mathrm{b}$ & 1.48 & .08 & $<.001$ \\
\hline \multirow[t]{3}{*}{ Sabit } & $i$ & 36.39 & 1.9 & $<.001$ & $i_{2}$ & 47.1 & 4.6 & $<.001$ \\
\hline & 1 & & 5 & & & 6 & 8 & \\
\hline & & $\begin{array}{l}\mathrm{R}^{2}=, 03 \\
\mathrm{~F}(1,52\end{array}$ & $8, p<$ & & & $\begin{array}{l}5 \\
521)=\end{array}$ & 80 & \\
\hline
\end{tabular}

Tablo 5.'de gösterilen değerlere bakıldığında durumu affetmenin akılcı olmayan inanç ile öz-anlayış arasındaki ilişkide aracılık etkisinin olup olmadığını belirlemek amacıyla yapılan regresyon analizi sonucunda "a" yoluna ilişkin regresyon modelinin anlamlı olduğu görülmektedir $\left(\mathrm{R}^{2}=.03 ; \mathrm{F}(1\right.$, $521)=18.98 ; \mathrm{p}<.001)$.

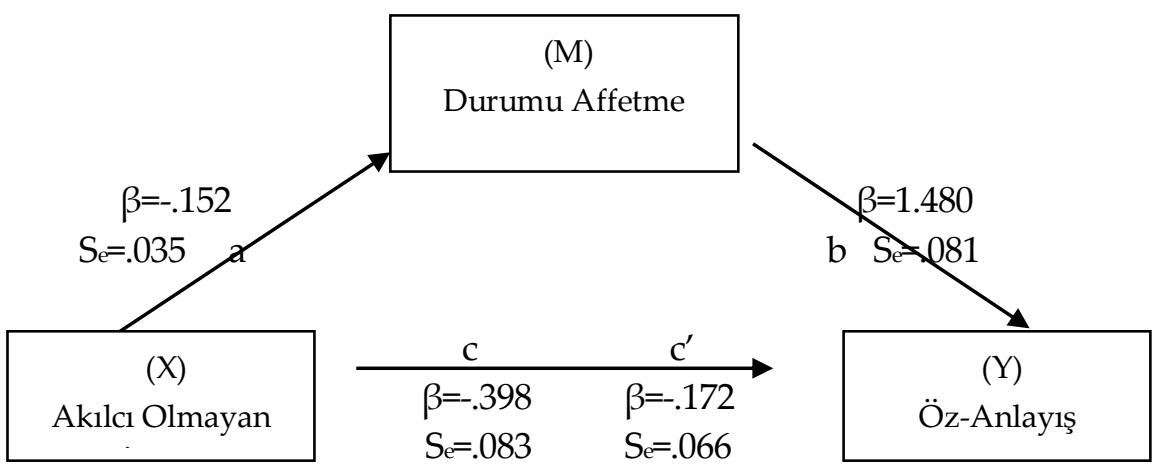

Şekil 5. Durumu Affetme Aracılık İlişkisinin Araştırma Modeli Sonucu

Şekil 5.'te de görüldüğü üzere akılcı olmayan durumu affetmeyi ( $a=\beta=-$ .15; p<.001) anlamlı düzeyde etkilemektedir. Akılcı olmayan inancın etkisi 
kontrol edilirken durumu affetmenin öz-anlayışı anlamlı düzeyde etkilediği görülmüştür ( $b=\beta=1.48 ; p<.001)$. Aracı değişken olan durumu affetme modele dahil edildiğinde araştırmanın bağımsız değişkeni akılcı olmayan inancın bağımlı değişken öz-anlayışı etki düzeyini -.40'dan -.17'ye düşürdüğü görülmüştür. Aracılık analizine dair bulgular incelendiğinde durumu affetme aracı değişken olarak modele dahil edildiğinde akılcı olmayan inancın özanlayış üzerindeki anlamlı etkisi devam etmiş ancak etkinin derecesi azalmıştır. Sonuç durumu affetmenin akılcı olmayan inanç ile öz-anlayış arasındaki ilişkide kısmi aracı rol oynadığını gösterir. Analiz sonucu akılcı olmayan inançların durumu affetme aracıllı̆ı̀yla öz-anlayış düzeyi üzerindeki dolaylı etkiler toplamının anlamlı olduğunu göstermektedir $(\beta=-.22$, BootLLCI=-.33 ile BootULCI=.11). Araştırmanın bir diğer sonucunda da aracı değişken olan durumu affetmenin modele dahil edilmesiyle akılcı olmayan inançların affetme ile birlikte öz-anlayış düzeylerinde gözlenen varyansın \%41'ini açıkladığ görülmektedir $\left(R^{2}=.41 ; F(1,521)=184.80\right.$, $\mathrm{p}<.001)$. Sonuç olarak H4 hipotezi kabul edilmiştir ve kurulan model doğrulanmıştır.

\section{Tartışma ve Sonuç}

\section{Akılcı Olmayan İnanç ile Öz-Anlayış Arasındaki İlişkide Affetmenin Aracı Rolüne İlişkin Tartışma:}

Yapılan araştırma sonucunda akılcı olmayan inançların öz-anlayış düzeyini negatif yönde ve anlamlı düzeyde etkilediği görülmüştür. Akılcı olmayan inanç ve öz-anlayışın ana temalarının birbirine yakın olması, temelde kişiye fayda sağlamayan, gerçeklikten uzak, kişinin benliğini kabul etmesini engelleyen düşüncelerden uzaklaşması gerekliliğini konu edinmesi aralarındaki bu anlamlı ilişkiyi açıklamaktadır. Alanyazında bu sonuçlarla örtüşecek nitelikte olan çalışmalarda bireylerin uyumlu psikolojik işlev (Neff vd. 2006) ve ruh sağlıkları (Kirkpatrick, 2005) ile pozitif ilişkili olan öz-anlayışın; bilişsel çarpıtmalarla negatif ilişkili (Akın,2010) olduğu görülmüştür. Yine araştırma sonucuna paralel olarak Stephenson ve vd. (2017) bireyin kendine karşı şefkatinin Akılcı Duygusal Davranış̧̧ı Terapideki rahatsız edici yaşam olaylarının değerlendirilme aşamasında devreye giren mantık dışı inançlara müdahale etme işlevinin olduğunun vurgusunu yapmaktadır ve öz- 
anlayışın, akılcı olmayan inançların kişide ortaya çıkardığı duygusal rahatsızlıklara karşı tampon görevi gördüğünü ifade etmektedir. Literatür incelendiğinde bu araştırma sonucu ile örtüşen deneysel çalışma da (Akın,2009) geliştirilen psikoeğitim programıla bireyin hata yapabilir bir varlık olduğunu kabul ederek, benliğini zedeleyen düşüncelerden uzaklaşması ve kendine karşı daha nazik davranması sağlanmış ve öz-anlayış düzeyinin arttığ1 görülmüştür. Araştırmada elde edilen bir diğer bulguda da akılc1 olmayan inancın bireylerin affetme düzeylerine olan etkisi negatif yönde ve istatistiksel olarak anlamlı bulunmuştur. Araştırma sonucuyla parallel olarak bireylerin affetme eğilimlerinin artması için kişiye acı verenlere karşı duygu, düşünce ve davranışlarında bir değişimin olması gerekliliği vurgulanmaktadır (Enright, 1996). Katı, abartılı, işlevsiz ve kişiye zarar veren inançların değişmesi bireyin daha esnek düşünebilmesine yardımcı olacaktır. Daha esnek düşünebilen birey yaşantılara ve hatalara karşı daha kabul edici yaklaşabilecektir. Bunun da affetme eğiliminin artmasına neden olabileceği söylenebilir.

Yapılan analizler sonucunda akılcı olmayan inancın öz-anlayış üzerindeki etkisi affetme modele dahil edildiğinde azalmıştır. Bu sonuca göre akılCl olmayan inancın öz-anlayış üzerindeki etkisinin büyük olasılıkla affetme üzerinden ortaya çıktığı söylenebilir. Yani akılcı olmayan inanç öz-anlayışı açıklamada tek başına yeterli değildir. Affetme değişkeninin kısmi olarak akılcı olmayan inanç ile öz-anlayış arasındaki ilişkide aracılık ettiği yorumu yapılabilir. Bu araştırmaya benzer bir çalışmada da Breen ve vd. (2010) bireylerin affetme ve öz-anlayış düzeyleri arasında olumlu ve istatistiksel olarak anlamlı bir ilişki olduğunu belirtir. Benzer şekilde Asıcı (2013) özduyarlılığın olumlu alt boyutları ile (öz-sevecenlik, paylaşımların bilincinde olma ve bilinçlilik) bireylerin genel affetme düzeyleri arasında olumlu ve istatistiksel olarak anlamlı bir ilişki bulmuştur. Bu araştırma sonucunda elde edilen bulgularla paralellik gösteren araştırmalarda; depresyon ve kaygı ile negatif yönde ilişkili bulunan affetmenin de (Lee,2011) öz-anlayışın da (Neff, 2003a; Thompson,2005) bireyin psikolojik sağlığı için önemli ve gerekli iki kavram olduğu söylenebilir. Yapılan çalışmalar affedicilik ile genel iyilik hali arasında olumlu yönde ilişki olduğunu (Lee,2011) ve öz-anlayışın da psikolojik sağlığı açıklamada olumlu etkisi olduğunu (Kirkpatrick, 2005) desteklemektedir. Öz-anlayış ve affetmenin duygu düzenleyici rolleri olduğu düşünüldüğünde birbirlerini etkilemeleri olası görünmektedir. Psikolo- 
jide olumlu bir psikolojik özellik olarak kabul gören affetme (Gangdev, 2009) bireyin inciten kişiye karşı duygu, düşünce ve davranışlarını değiştirmesiyle mümkün olabilecektir. Öz-anlayışın temelinde var olan kişinin kendisine merhamet duyması ve olumsuz yaşantılarını kabul edebilmesi affetme ile ilişkili görünmektedir.

\section{Akılcı Olmayan İnanç ile Öz-Anlayış Arasındaki İlişkide Kendini Affetmenin Aracı Rolüne İlişkin Tartışma}

Araştırmada akılcı olmayan inanç ile kendini affetme arasında negatif yönde anlamlı bir ilişki olduğu görülmüştür. Bu sonuçla paralel olan araştırmada Enright (1996) olumsuz yaşam olaylarında bireyin kendine olan affediciliği arttı̆̆ında birey işlevsel olmayan düşünce ve eylemlerinin farkına varıp, bunları değiştirme motivasyonuyla birlikte kendine karşı bir anlayış geliştirir. Yani kendilerini affedebilen bireyler akılcı olmayan inançlarının azaltılması ya da giderilmesinde büyük öneme sahip duygu, düşünce ve davranışlarında değişim göstermektedirler. Bu araştırma sonucu bilişsel çarpıtmaların (Gündüz, 2014), kişisel rahatsızlık ve ruminatif düşüncelerin (Aşç1oğlu Önal, 2014) kendini affetmeyi olumsuz yönde ve anlamlı düzeyde yordayan çalışmaları destekler niteliktedir. Araştırmada öz-anlayış ile kendini affetme arasında da pozitif yönde, güçlü ve anlamlı bir ilişki bulunmuştur. İyileştirici bir güç olan kendini affetme eğiliminde olan bireylerin bu araştırmayla örtüşen çalışmada (Mistler, 2010) bireyin kendine karşı cezalandırıcı olmayan, aksine sevgiyle ve anlayışla yaklaşan bir yapıya sahip oldukları belirtilir. $\mathrm{Bu}$ araştırma ile uyumlu olan alanyazındaki diğer araştırmalarda da (Ası11,2013; Dolunay Cuğ, 2015; Oral,2016; Sarıçam ve Biçer, 2015; Sayın, 2017) bireyin öz-anlayış düzeyi arttıkça kendini affetme davranışı artmaktadır. Öz-anlayışları yüksek olan bireyler kendi faydalarına olan kendini affetme davranışında daha çok bulunuyor olabilirler.

Araştırmanın kendini affetme analizine dair bulgular incelendiğinde kendini affetme aracı değişken olarak modele dahil edildiğinde akılcı olmayan inancın öz-anlayış üzerindeki anlamlı etkisi anlamsızlaşmıştır. Bu anlamsızlaşma kendini affetmenin akılcı olmayan inanç ile öz-anlayış arasında tam aracı rol oynadığını göstermektedir. Bu araştırma sonucundaki tam aracılıkta akılcı olmayan inanç kendini affetmeyi etkilemekte; kendini affetme ise öz-anlayışın nedeni olmaktadır. Sonuç olarak akılcı olmayan inanç 
ile öz-anlayış arasında dolaylı bir nedensellik ilişkisi olduğu söylenebilir. Alanyazın incelendiğinde bu çalışmaya benzer bir aracılık çalışmasına rastlanılmamıştır. Ancak bireyin hissettiği suçluluktaki azalmaların (Hall ve Fincham, 2008) ve kendine yönelik olumsuz değerlendirmelerin azaltılmasının Dillon (2001) kendini affetmeyi arttırdığına dair çalı̧malar mevcuttur. Bireyin mantık dışı inançlarını terk edip duygu, düşünce ve davranışlarını daha işlevsel yönetebilmesinin hem kendisiyle hem başkalarıyla hem de dünya ile ilişkilerinde sağlıklı bir yapı oluşturacağı düşünülmektedir. Akılcı olmayan inançları terk eden birey beklentilerini daha gerçekçi değerlendirebilecek özellikle kendine karşı acımasız tutumunu terk edebilecek ve kendini kusurlarıyla kabul edebilen birey olabilecektir. Bu akılcı olmayan inançların azaltılmasıyla bireyde yıkıcı duyguların da azalacağı, böylelikle bireyin kendine dönük affediciliğin artacağı söylenebilir. Kendini affetmeyi becerebilen, kendine sevgiyle yaklaşabilen bireyin öz-anlayış düzeyi de artacaktır.

\section{Akılcı Olmayan İnanç ile Öz-Anlayış Arasındaki İlişkide Başkaların Af- fetmenin Aracı Rolüne İlişkin Tartışma}

Araştırmada akılcı olmayan inanç ile başkalarını affetme arasında anlamlı bir ilişki bulunmamıştır. Affetmenin alt boyutu olan başkalarını affetme ve akılcı olmayan inançları birlikte ele alan çalışmalar kısıtlı olmakla birlikte Aşçıŏlu Önal (2014)'ın araştırmasında bu araştırma sonucunun tersine ilişkilerle ilgili bilişsel çarpıtmaların yalnızca yakınlıktan kaçınmaya alt boyutunun başkalarını affetmenin anlamlı düzeyde yordayıcısı olduğunu görülmüştür. $\mathrm{Bu}$ araştırmada kullanılan akılcı olmayan inanç kısa formunda daha çok kişinin kendine dönük özel ifadelerin bulunması ve diğer bireylerle ilgili ifadelerin az olması bu sonucu etkileyebilir. Bir diğer bulguda ise özanlayış ile başkalarını affetme arasında pozitif yönde anlamlı bir ilişki görülmüş̧ür. Araştırma sonucu ile paralellik gösteren bir araştırmada (Asıcl, 2013) öz-anlayış ile başkalarını affetme arasında düşük fakat anlamlı bir ilişki görülmüştür. Öz-anlayışın psikolojik sağlık (Kirkpatrick, 2005) açısından önemi ve faydası düşünüldügünnde başkalarını herhangi bir hatadan sonra affeden kişinin intikam duygularından arınarak psikolojik sağlı̆̆ını koruyabileceği söylenebilir (McCullough ve vd., 1998). Bu bulgu araştırma sonucu ile benzer görünmekle birlikte yaşanan acı verici deneyimler sonucunda bireyin, bu durumu insanoğlunun birçoğunun yaşadığı deneyimin 
bir parçası olarak görmesi ve empati kurabilmesiyle başkalarını affetme davranışını da arttırması söz konusu olabilir. Bir başka benzer araştırmada da (McCullough vd. 1997) yaşanan olumsuz deneyimlerin kişinin rahatsız edici düşünce ve değerlendirmelerin kişide empati yeteneğini azaltarak ya da empati kurmasını engelleyerek diğer diğer bireyleri affetmesini zorlaştırabileceği görülmüştür. Başkalarını affetmenin akılcı olmayan inanç ile özanlayış arasında aracı etkisinin olmadığı görülmüştür. Affetmenin son zamanlarda araştırmalarda sıkça yer almasıyla birlikte başkalarını affetmenin aracı etkisinin araştırmalarda çok fazla yer bulmaması tartışılmasını güçleştirmektedir.

\section{Akılcı Olmayan İnanç ile Öz-Anlayış Arasındaki İlişkide Durumu Affetmenin Aracı Rolüne İlişkin Tartışma}

Durumu affetmenin akılcı olmayan inanç ile olumsuz yönde ve anlamlı, özanlayış ile de olumlu yönde ve anlamlı bir ilişkide olduğu görülmüştür. Alanyazın incelendiğinde affetmenin daha çok kendini ve başkalarını affetme boyutlarının ele alındığı durumu affetme ve öz-anlayışı içeren araştırmaların daha sınırlı olduğu görülmektedir. Araştırmayla paralel olan çalışmalar (Breen, Kashdana, Lenser ve Fincham, 2010; Sarıçam ve Biçer, 2015) da mevcuttur. Affetmenin bireyde bitirilmemiş işlerin tamamlanması ve rahatlama sağlaması öz-anlaysşla paralel görünmektedir. Kendine değer veren, hatalarını kabul eden, duygularını yönetebilen ve çektiği acıyı azaltmak isteyen bireyin yaşadığı acı verici olaylara karşı daha affedici olması beklenmektedir. $\mathrm{Bu}$ acı verici olayın birçok insan tarafından yaşandığını, yalnız olmadığını ve üstesinden mantıklı bir bilinçle gelinebileceğini fark eden birey yaşadığı durumu daha kolay affedebilecek ve kabul edebilecektir. Aracı değişken olan durumu affetme modele dahil edildiğinde akılcı olmayan inancın öz-anlayış üzerindeki etkisinin düştüğü görülmüştür. Yani akılcı olmayan inancın öz-anlayış üzerinde anlamlı bir etkisi vardır ancak durumu affetme modele girdirildiğinde bu anlamlı etkisi azalmıştır ve durumu affetmenin kısmi aracı rol oynadığını göstermektedir. Anlamlı etkideki bu düşüşün sebebi akılcı olmayan inancın öz-anlayış üzerindeki etkisinin büyük olasılıkla durumu affetme üzerinden ortaya çıkması olarak yorumlanabilir. Yani bireydeki öz-anlayış düzeyi hem akılcı olmayan inançların varlı̆̆ından hem de durumu affetme özelliklerinden etkilenmektedir. Öz- 
anlayış ve durumu affetmenin birbirini destekleyen ve etkileyen yapısı bu araştırma sonucuna paralel olarak desteklenmektedir. Thompson ve vd. (2005) bireylerin olumsuz yaşantılarına, kaderine, o duruma ve hastalıklarına karşı isyan edici cevaplarını değiştirdiğinde olumsuza dönen duygularını olumluya ya da nötre dönüştürebileceğini böylelikle affediciliğin de sağlanacağını söyler. Aynı zamanda öz-anlayışın yaşanılan olumsuz yaşantılar sonrasında gösterilen duyuşsal ve bilişsel tepkileri de yordaması (Leary ve vd., 2007) bireyi olumsuz duygulardan koruyucu etkisini de göstermektedir. Bireylerin sahip olduğu akılcı olmayan inançlar düşünüldügünde kendine, diğer insanlara ya da herhangi bir yaşantıya dönük beklentileri, inançları ve düşünceleri vardır. Bu inançlar bireyin kendisine ve diğer bireylere olduğu kadar bir yaşantıyı değerlendirmeyi, o yaşantı hakkındaki yorumlamaları da içerir. Fakat yaşanan olayların yalnızca kişiye özgü olmadığını, tüm insanların benzer yaşantılarla karşılaştığını bilen birey bu karşılaştığ acı verici durumu da kabullenebilir ve affedebilir. Yaşanan bu duruma affedici yaklaşabilen birey yalnız olmadığını ve bu problemle başa çıkabileceğini düşünerek kendine karşı anlayışının yani öz-anlayışının artması beklendik bir durumdur.

Sonuç olarak akılcı olmayan inançlar ve affetme modelleri temel alınarak geliştirilmiş psikoeğitim programlarının varlığı alanyazında görülmektedir. Değişkenler arasındaki var olan anlamlı ilişkiler göz önünde bulundurulduğunda bu değişkenlerin birbirlerini etkileyen yapıda oldukları ve bireylerin öz-anlayış düzeylerini arttıracak daha fazla psikoeğitim modellerinin geliştirilmesi alana önemli katkı sağlayacaktır. Genç yetişkinlerle yapılan bu araştırma farklı yaş gruplarıyla da yapılabilir. Affetme ve öz-anlayışın olumlu psikolojik işlevlere sahip olması ve bireylerde geliştirilmesi gereken özellikler olması nedeniyle okullardaki eğitim programlarına ve rehberlik faaliyetlerine affetme ve öz-anlayış konularının eklenmesi önerilmektedir. 


\title{
EXTENDED ABSTRACT
}

\section{The Mediator Role of Forgiveness In The Relationshıp Between Irrational Beliefs And Self- Compassion Among Young Adults}

\author{
Defne Kılıç - Erhan Tunç \\ Gaziantep University
}

Young adulthood, an important period in human life, is one of these periods. Individuals in young adulthood are assumed to mature physically and psychologically and are expected to solve the problems they face by moving away from emotionality by thinking and acting more rationally (Kılıç, 2013). When individuals are assumed to be born with their tendency to acquire rational and irrational beliefs, they should have more rational solutions and expectations in their lives. The individual must "should accept gracefully" all the inevitable lives that are under control or not, which disturbs him and strives to improve and regulate his emotions (Ellis \& Harper, 2017). Trying to regulate emotions will help the individual overcome problems at the cognitive level (Garnefski et al. 2001). Self-understanding is also an emotional regulation strategy (Neff, 2003a), and self-understanding is expected to increase with decreasing irrational beliefs as it is considered as the person's ability to cope with destructive feelings such as inadequacy and failure. SelfUnderstanding, rather than the harsh and brutal approach of the individual after the devastating life events experienced by the individual; is that these negative events are an experience that many people experience and that they can consciously cope with these painful feelings and thoughts instead of isolating themselves from life (Neff, 2003a).

Forgiveness is an individual's empathic approach to him, thinking that there is a possibility of misunderstanding, making mistakes, instead of escaping or moving away from the injustice, and feeling positive emotions by getting out of his feelings of anger and revenge (Worthinton, 1998). It will be possible to get rid of destructive emotions with self-understanding, ie selfunderstanding (Oral, 2016), and individuals will change positively by acting forgiving not only against themselves but also against other people and 
events. Forgiveness plays an important role in the change of annoying emotions of individuals and in dealing with these emotions.

The aim of this study is to examine the mediating roles of forgiveness and forgiveness, self-forgiveness, and forgiveness of the situation, in the relationship between the irrational belief and self-understanding levels of young adults. The sample of the study consisted of 523 students studying at various faculties of Gaziantep University undergraduate, postgraduate and pedagogical formation program. "Irrational Belief-K Form", "SelfUnderstanding Scale" and "Heartland Forgiveness Scale" were used as data collection tools. PROCESS v.3.3, the SPSS macro program in the analysis of data. was used and the process was carried out using the regression model. As a result of the analysis, when we look at the mediating effect in the relationship between irrational belief and self-understanding, it is seen that forgiveness and forgiveness have a partial means and self-forgiveness has a full mediating effect in this relationship. It was observed that there is no mediating effect of forgiving others between irrational belief and selfunderstanding.

As a result of the research, self-understanding decreases as the irrational belief increases. Stephenson et al. (2017) emphasizes that the compassion of the individual towards himself is the function of interfering with irrational beliefs that come into play in the evaluation stage of the disturbing life events in the Rational Emotional Behavioral Therapy and states that selfunderstanding acts as a buffer against the emotional disturbances caused by irrational beliefs in the person.

A negative relationship was found between irrational belief and forgiveness, forgiveness and forgiveness. However, there was no significant relationship with forgiving others. In order to increase the tendency of individuals to forgive, Enright (1996) emphasizes that there should be a change in their feelings, thoughts and behaviors towards those who suffer.

In the research, a positive relationship was found between selfunderstanding and self-forgiveness, forgiving others and forgiving the situation. In a study by Mistler (2010), it is stated that the individual has a structure that does not punish himself, but that approaches with love and understanding. Considering the importance and benefit of self-understanding in terms of psychological health (Kirkpatrick, 2005), it can be said that the person who forgives others after any mistake can protect their psychological 
health by removing their feelings of revenge (McCullough et al., 1998). Thompson et al. (2005) states that when individuals change their rebellious responses to their negative lives, destinies, conditions and diseases, they can transform their negative feelings into positive or neutral so that forgiveness will be provided.

As a result of intermediary analysis;

1. Forgiveness has been observed to have a partial mediating role in the relationship between irrational belief and self-understanding. According to this result, it can be said that the effect of irrational belief on selfunderstanding is most likely caused by forgiveness. Studies support that there is a positive relationship between forgiveness and general well-being (Lee, 2011) and self-understanding has a positive effect on explaining psychological health (Kirkpatrick, 2005). Considering that self-understanding and forgiveness have emotion-regulating roles, it seems likely that they affect each other. Forgiveness (Gangdev, 2009), which is accepted as a positive psychological feature in psychology, will be possible by changing the feelings, thoughts and behaviors of the individual against the injured person.

2. It has been observed that self-forgiveness has a full mediating role in the relationship between irrational belief and self-understanding. As a result, it can be said that there is an indirect causal relationship between irrational belief and self-understanding. Reducing the guilt reductions (Hall and Fincham, 2008) and self-negative evaluations of the individual increases Dillon (2001) forgiveness. It is thought that the individual's abandoning his irrational beliefs and managing his/her emotions, thoughts and behaviors more functionally will create a healthy structure in his relations with himself/herself, others and the world. The level of selfunderstanding of the individual who can manage to forgive himself and approach himself with love will also increase.

3. It has been observed that forgiving the situation has a partial mediating role in the relationship between irrational belief and self-understanding. In other words, the level of self-understanding in the individual is affected by both the existence of irrational beliefs and the characteristics of forgiving the situation. The structure of self-understanding and forgiveness supporting and influencing each other explains the results of this research. As a result of the research, it was observed that forgiving ot- 
hers did not play a mediating role in the relationship between irrational belief and self-understanding.

Considering the meaningful relationships between the variables, the development of more psychoeducation models that these variables have a structure affecting each other and that will increase the level of selfunderstanding of individuals will contribute significantly to the field. This research with young adults can also be done with different age groups. Considering the meaningful relationships between the variables, the development of more psychoeducation models that these variables have a structure affecting each other and that will increase the level of selfunderstanding of individuals will contribute significantly to the field.

\section{Kaynakça / References}

Akın, A. (2009). A Aklcı duygusal davranış̧ı terapi odaklı grupla psikolojik danışmann iyi olma ve öz-duyarlk üzerindeki etkisi. Doktora tezi. Sakarya Üniversitesi Sosyal Bilimler Enstitüsü.

Akın, A. (2010). Self-compassion and interpersonal cognitive distortions. Hacettepe Üniversitesi Eğitim Fakültesi Dergisi (H.U. Journal of Education), 39, 01-09.

Aktu, Y. (2016). Levinson'un kuramında ilk yetişkinlik döneminin yaşam yapısı. Psikiyatride Güncel Yaklaşımlar, 8(2), 162-177.

Asıc1, E. (2013). Öğretmen adaylarmmn affetme özelliklerinin öz-duyarlk ve benlik saygısı açısından incelenmesi. Yüksek lisans tezi. Dokuz Eylül Üniversitesi Eğitim Bilimleri Enstitüsü.

Aşçığlu Önal, A. (2014). Bilişsel çarpttmalar, empati ve ruminasyon düzeyinin affetmeyi yordama gücünün incelenmesi. Yüksek Lisans Tezi Ankara Üniversitesi Eğitim Bilimleri Enstitüsü.

Bacanll, F. (2012). Kariyer karar verme güçlükleri ve meslek seçimine ilişkin akıla olmayan inançların etkisi. Türk Psikolojik Danışma ve Rehberlik Dergisi, 4(37), 86-95.

Bugay, A. ve Demir, A. (2010). A turkish version of heartland forgiveness scale. Procedia Scial and Behavioral Sciences, 5, 19271931.doi:10.1016/j.sbspro.2010.07.390

Bugay. A. ve Demir. A, (2012). Affetme arttrrlabilinir mi? : Affetmeyi geliştirme grubu. Türk Psikolojik Damısma ve Rehberlik Dergisi, 4(37), 96-106.

Büyüköztürk, Ş., Akgün, Ö., Karadeniz, Ş., Demirel, Z. ve Çakmak, E. (2012). Bilimsel araştırma yöntemleri. Ankara: Pegem Yayıncllk 
Çapan, B. E. ve Arıcıŏglu, A. (2014). Psikolojik sağlamlı̆̆ın yordayıcısı olarak affedicilik. e-Uluslararası Ĕ̆itim Araştırmalan Dergisi, 5(4), 70-82.

Deniz, M. E. Kesici, Ş. ve Sümer, S. A. (2008). The validity and reliability of the turkish version of the self-compassion scale. Social Behavior And Personality, 36(9), 1151-1160.

Deniz, M. E. Amanvermez, Y. ve Buyruk-Genç, A. (2017). Ruminasyon ve yaşamda anlamın farklı öz-anlayış düzeylerine göre incelenmesi. Kalem Eğitim ve İnsan Bilimleri Dergisi, 7(2), 353-372.

Dillon, R.S. (2001). Self-forgiveness and self-respect. Ethics, 112, 53-83.

Dolunay Cuğ, F. (2015). Self-forgiveness, self-compassion, subjective vitality, and orientation to happiness as predictors of subjective well-being. (Ph.D., Department of Educational Sciences). The Graduate School Of Social Sciences Middle East Technical University.

Ellis, A. (1994). Reason and emotion in psychotherapy: A comprehensive method of treating human disturbances. New York: Birch Lane Press.

Ellis, A. (1995). Changing rational-emotive therapy (RET) to rational emotive behavior therapy (REBT). Journal of Rational-Emotive \& Cognitive-Behavior Therapy, 13(2), 85-89.

Ellis, A. ve Harper, R.A. (2017). Akllcı yaşam kılavuzu. (S. H. Akbaş, Çev.). Ankara: Eksi Kitaplar. (Orijinal çalışma basım tarihi 1997).

Enright, R.D. (1996). Counseling within the forgiveness triad: On forgiving, receiving forgiveness, and self forgiveness. Counseling and Values, 40(2), 107-126.

Fitzgibbons, R. P. (1986). The cognitive and emotive uses of forgiveness in the treatment of anger. Psychotherapy: Theory, Research, Practice, Training, 23(4), 629-633.

Gangdev, 2009. Forgiveness: A not for psychiatrists. Indian J Psychiatry, 51(2), 153-156.

Garnefski, N., Kraaij, V., ve Spinhoven, P. (2001). Negative life events, cognitive emotion regulation and emotional problems. Personality and Individual Differences, 30, 1311-1327.

Gündüz, Ö. (2014). Üniversite öğrencilerinde affetmeyi yordayan değişkenlerin belirlenmesi. (Yüksek lisans tezi). Ankara Üniversitesi Eğitim Bilimleri Enstitüsü.

Hall, J.H. \& Fincham, F.D. (2005). Self-forgiveness: The stepchild of forgiveness research. Journal of Social and Clinical Psychology, 24(5), 621-637.

Hall, J. H. ve Fincham, F. D. (2008). The temporal course of self-forgiveness. Journal of Social and Clinical Psychology, 27 (2), 174-202.

Hayes, A. (2013). Introduction to Mediation, Moderation, and Conditional Process Analysis A Regression-Based Approach. New York, Gulford Press. 
Hebl, J. H., ve Enright, R.D. (1993). Forgiveness as a psychotherapeutic goal with elderly females. Psychotherapy, 30, 658-667.

Karasar, N. (2016). Bilimsel araştırma yöntemi (31.baskı).Ankara:Nobel Akademi Yayıncllik

Kaya, İ. (2010). Anne-babalarm aklcı olmayan inançları ölçeğinin geliştirilmesi ve psikometrik özelliklerinin incelenmesi. Yüksek lisans tezi. Gaziantep Üniversitesi, Sosyal Bilimler Enstitüsü.

Kulıç, M. (2013). Gerçek yaşam tadında: Gelişim dönemleri 3 yetişkinlik ve yaşllık. Pegem Akademi, ss. 21.

Kirkpatrick, K.LeClair (2005). Enhancing Self-Compassion Using a Gestalt Two- Chair Intervention. University of Texas at Austin, Unpublished doctoral dissertation.

Leary,M.R., Adams, C.E., Allen, A.B., ve Hancock, J.(2007). Self-compassion and reactions to unpleasant self-relevant events: The implications of treating oneself kindly. Journal of Personality and Social Psychology, 92, 887-904.

Lee, K. H. (2011). The role of spiritual experience, forgiveness, and religious support on the general well-being of older adults. Journal of Religion, Spirituality $\mathcal{E}$ Aging, 23(3), 206-223.

Levinson, D. J., (1986). A conception of adult development. American Psychologist, 41(1), 3-13.

McCullough, M. E., Worthington, E. L., Rachal, K. C., Sandage, S. J., Brown, S. W. ve Hight, T. L. (1998). İnterpersonal forgiving in close relationships: ii. theoretical elaboration and measurement. Journal of Personality and Social Psychology, 75 (6), 1586-1603.

McGinn, L.K. (1997). Interview: Albert Ellis on rational emotive behavior therapy. American Journal of Psychotherapy. 51(3), 309.

Mistler, B. A. (2010). Forgiveness, perfectionism, and the role of self-compassion. (Unpublished $P h D$ Thesis). Gainesville: University of Florida.

Neff, K. D. (2003a). Self-compassion: An alternative conceptualization of a healthy attitude toward oneself. Self and Identity, 2(2), 85-101.

Neff, K. D. (2003b). The development and validation of a scale to measure selfcompassion. Self and Identity, 2(3), 223-250.

Neff, K. D., Kirkpatrick, K. L., \& Rude, S. S. (2006). Self-compassion and adaptive psychological functioning. Journal of Research in Personality, 41, 139-154.

North, J. (1987). Wrongdoing and forgiveness. Philosophy, 62, 499-508.

Oral, T. (2016). Üniversite öğrencilerinin affetme düzeylerinin öz-anlayış, kişilerarası hataya ilişkin ruminasyon ve kişilik özellikleri açısından incelenmesi. (Doktora tezi). Necmettin Erbakan Üniversitesi Eğitim Bilimleri Enstitüsü. 
Sarıçam, H. ve Biçer, B. (2015). Affedicilik üzerinde ahlaki değer ve öz-anlayışın açılayıcı rolü. GEFAD/ GUJGEF, 35, 109-122.

Sayın, M. (2017). Üniversite öğrencilerinin öz-anlayıs, kendini affetme ve başa çıkma stratejileri arasındaki ilişkiler örüntüsü: bir yol analizi çalışması. (Yüksek lisans tezi). Marmara Üniversitesi Eğitim Bilimleri Enstitüsü.

Seligman ME, Steen T, Park N, Peterson C. (2005). Positive psychology progress: empirical validation of interventions. Am Psychol. 60 (5), 410-425.

Stephenson, E., Watson, P. J., Chen, Z. J. ve Morris, R. J. (2017). Self-compassion, selfesteem and irrational beliefs. Current Psychology, 37(4), 809-815.

Şahin, C. (2009). Eğitim fakültesinde öğrenim gören öğrencilerin umutsuzluk düzeyleri. Selçuk Üniversitesi Ahmet Keleşoğlu Eğitim Fakültesi Dergisi., 27, 271 286.

Taysi, E. (2007). İkili ilişkilerde bağı̧ılama: IIlişki kalitesi ve yüklemelerin rolü. (Doktora tezi). Ankara Üniversitesi Sosyal Bilimler Enstitüsü.

Thompson, L. Y., Snyder, C. R., Hoffman, L., Michael, S. T., Rasmussen, H. N. ve Billings, L. S. (2005). Dispositional forgiveness of self, others, and situations. Journal of Personality, 73 (2), 313-359.

Türküm, A.S. (2003). Akılcı olmayan inanç ölçeğinin geliştirilmesi ve kısaltma çalısmaları. Türk Psikolojik Danışma ve Rehberlik Derneği, 2(19), 41-47.

Wade, N. G. ve Worthington, E. L., Jr. (2005). In search of a common core: A content analysis of interventions to promote forgiveness. Psychotherapy: Theory, Research, Practice, Training, 42 (2), 160-177.

Worthington, E. L. (1998). An empathy-humility-commitment model of forgiveness applied within family dyads. Journal of Family Therapy, 20(1), 59-76.

\section{Kaynakça Bilgisi / Citation Information}

Kılıç, D. ve Tunç, E. (2020). Genç Yetişkinlerde akılcı olmayan inanç ile öz- anlayış arasındaki ilişkide affetmenin aracı rolü. OPUSUluslararası Toplum Araştırmaları Dergisi, 16(Eğitim ve Toplum Özel Sayıs1), 6244-6270. DOI: 10.26466/opus.735586 